\title{
IAMJ
}

INTERNATIONAL

AYURVEDIC

MEDICAL JOURNAL

\section{EFFECTIVENESS OF SAHACHARADI TAILAM FOURTEEN TIMES AVARTHI WITH PRE-MEDICATION IN QUALITY OF LIFE OF PARKINSON'S DISEASE AS AN ADD ON TO MODERN MEDICINE}

\author{
Jinsa I ${ }^{1}$, K Miharjan ${ }^{2}$, Chitra $\mathbf{P}^{3}$ \\ ${ }^{1}$ Assistant professor Dept. of Kayachikitsa, Parassinikadavu Ayurveda Medical College, Kannur, Kerala, India \\ ${ }^{2}$ Retired Professor, Dept. of Kayachikitsa, Govt. Ayurveda College, Thiruvananthapuram, Kerala, India \\ ${ }^{3}$ Additional Professor Dept. of Neurology, Govt. Medical College, Thiruvananthapuram, Kerala, India
}

Corresponding Author: jinsaiknr@gmail.com

\section{https://doi.org/10.46607/iamj03p6012021}

(Published online: November 2021)

Open Access

(C) International Ayurvedic Medical Journal, India 2021

Article Received: 17/09/2021 - Peer Reviewed: 19/11/2021 - Accepted for Publication: 22/11/2021

\section{Check for updates}

\section{ABSTRACT}

Parkinsons disease (PD) is an idiopathic degenerative disorder that affects mainly old age. Community-based prevalence studies from India have documented crude prevalence rates of PD from 7 to 328 per 100,000 in the overall population. The current management in PD is effective in alleviating signs and symptoms but the quality of life is not preserved. This study was undertaken to the clinical evaluation of Sahacharadi Tailam fourteen times Avarthi with premedication in improving the quality of life in Parkinson's patients. Since Kapha and Vata plays an important role in Samprapthi of Parkinson's disease, Kapha Vatha Hara Chikitsa should be effective. All types of Sneha Dravya are used in Vatha Vyadhi Chikitsa and Taila is more effective when Vatha is associated with Kapha. Most of the drugs in Sahachaadi Tailam have Vata Kapha Hara properties. The study design was an interventional study pre and post evaluation with a sample size of ten patients. Parkinson's disease of age group 40-70 years of both sex attending the OPD and IPD of Department of Kayachikitsa, Govt. Ayurveda College, Thiruvananthapuram was selected for the study. The patient selected for the study was subjected to DeepanaPachana with Gandharvahastadi Kashayam $48 \mathrm{ml}$ at 7 am \& 7 pm one hour before food and vaiswanarachoorna 6 gm with Kasayam internally and Udvarthana with Kolakulathadi Choorna externally for 1-7 days, Snehapana with Rasnadasamoola Gritham starting with $25 \mathrm{ml}$ with increasing dosage for 3-7 days, abhyanga and Ushma Sveda with Balatailam and Virechana with Gandharveranda Tailam 30-45ml and Samsarjanakrama as a prepara- 
tory phase for the administration of study drug. Then patients received Sahacharadi Tailam fourteen times Avarthi for two months. Follow up was done 15 days after the intervention. On statistical analysis, there was a significant reduction in symptoms like tremor rigidity and pain before treatment, after Shodhana, after intervention \& after follow up assessments.

Keywords: PD, Sahacharadi Tailam fourteen times Avarthi, Deepana- Pachana, Udvarthana, Snehapana, Abyanga, Ushma Sveda, Virechana, Samsarjana Krama, Kaphavatahara and Vata Vyadhi.

\section{INTRODUCTION}

Ayurveda - the traditional Indian system of medicine is the knowledge of life, the unique objective of which is the achievement of optimum health which includes maintenance and promotion of health in healthy individuals and cure of illness in diseased. This can be considered as the earliest scientific reference regarding the positive concept of health which can be achieved through a blending of physical, mental, social, moral \& spiritual well-being.

Parkinson's disease is named after Dr James Parkinson who was the first physician to describe the condition in 1817. He introduced the term shaking Palsy and described the affected individuals are having "involuntary tremulous motion, with lessened muscular power, in parts not in action and even when supported; with a propensity to bend the trunk forward and to pass from a walking to a running pace; the senses and intellect being uninjured". The term paralysis Agitans appeared for the first time in 1841 in Marshall Man's textbook, Disease and derangements of the nervous system ${ }^{[1]}$. Parkinson's disease (PD) is an idiopathic degenerative disorder that affects mainly old age ${ }^{[2]}$. Its peak age of onset is in the early $60 \mathrm{~s}$ (range 35-85 years), and the course of the illness ranges between 10 and 25 years. PD accounts for $\sim 75 \%$ of all cases of parkinsonism; the remaining cases result from other neurodegenerative disorders, cerebrovascular disease, and drugs ${ }^{[3]}$. The number of individuals with PD over the age of 50 in Europe's 5 most countries and 10 most populous nations was between 4.1 and 4.6 million in 2005 and will double to between 8.7 and 9.3 million by $2030 .{ }^{[4]}$ Community-based prevalence studies from India have documented crude prevalence rates of PD from 7 to 328 per 100,000 in the overall population. ${ }^{[5]}$
The current management in PD is effective in alleviating signs and symptoms but the quality of life is not preserved. It is observed that patients who received Sahacharadi Tailam fourteen times Avarthi with premedication as an add on to modern medicine show encouraging results in patients of Kayachikitsa ward. But it was not scientifically validated till now. The present study is to assess the quality of life of PD patients with Sahacharadi Tailam fourteen times Avarthi with premedication as an add on to modern medicine. PD is a neurodegenerative disease, in its due course reduces the quality of living of an individual. Hence, the individual poses a burden to the family members as well as to the society. Sahacharadi Tailam mentioned in Vatavyadhi Chikitsa with indications like Kampa (tremor) and Sthamba (rigidity), ${ }^{[6]}$ which are the main symptoms in PD, could be an apt option. PD is a disorder caused by the avarana of vatha by kapha, the drugs of Sahacharadi Tailam Being Vatakapha Samana and Taila being the mode of administration could rightly arrest the progression. This could be a breakthrough in our science.

PD is a long-term disorder that needs intake of medicine for a longer period. Even though L-dopa is the conventional management, long term usage results in levodopa-induced dyskinesia ${ }^{[7]}$. Sahacharadi Tailam could be an effective remedy with no side effects in long run.

\section{MATERIALS AND METHODS}

The study was an interventional study with pre and post evaluation. Patients with signs and symptoms of Parkinson's disease were selected as per the inclusion and exclusion criteria from the OPD and IPD of the Department of Kayachikitsa, Government Ayurveda College Hospital, Thiruvananthapuram. They were 
subjected to detailed clinical examination using a semi-structured clinical case proforma prepared as per modern and Ayurvedic parameters. The participants were again examined by a neurologist and detailed clinical evaluations and investigations were done. The confirmed cases were selected for the study.

\section{The setting for the study}

The patients were selected, who were diagnosed as having Parkinson's disease with proper documentation from OPD and IPD of the Department of Kayachikitsa, Govt. Ayurveda College Hospital, Thiruvananthapuram. Laboratory investigations were done at the pathology lab of Govt. Ayurveda College Hospital, Thiruvananthapuram.

\section{Study Population}

Patients with Parkinson's disease aged 40-70 years attending the IPD of Department of Kayachikitsa Government Ayurveda College Thiruvananthapuram.

\section{Sample}

The sample for the clinical study included patients diagnosed as having Parkinson's disease who reported at OPD and IPD of the Department of Kayachikitsa, Govt. Ayurveda College Hospital, Thiruvananthapuram during the study period.

\section{Inclusion Criteria}

Primary idiopathic Parkinson's disease aged 40- 70 years of both sex.

\section{Exclusion criteria}

Known case of ischemic heart disease

Patients undergo treatment for cerebrovascular accidents

Other extrapyramidal signs like dystonia, chorea, athetosis and myoclonus

Atypical Parkinson's disease and secondary parkinsonism

Normal-pressure hydrocephalus

Hypothyroidism

\section{Sample size}

The total sample size was ten.

\section{Duration of study}

The duration of the study was 86- 100 days.

\section{Collection of data}

The semi-structured case proforma was used as a tool for data collection in the study. The data collection was done by interrogation, physical examination and detailed examination of the nervous system, including investigations like haematological assessment.

\section{Preparation of the drug}

The study drug was taila. Drugs of good quality will be identified and brought from the market. These will be cleaned thoroughly and dried well. One part of sahachara along with its roots and branches, an equal quantity of dasamoola and half part of satavari are boiled in 10 times of water and decoction is reduced to one fourth the quantity. To this added the Kalka each of Sevya, Nakha, Kusta, Hima, Ela, Sprik, Priyangu, Misi, Turushka, Nata, Nalika, Ambu, Silajathu, Lohitha, Nalada, Loha, Devadaru and, Kopana one by $100^{\text {th }}$ of Sahachara. To this taila is added in the quantity $3 / 5^{\text {th }}$ of sahachara and an equal amount of milk and medicated oil is cooked. This taila is then subjected to fourteen times Avarthana ${ }^{[8]}$. By doing avarthi of tailam, it helps to minimize the dose, maximize the drug delivery and is easy to administer. It also helps in better packaging and marketing. The potency of sneha can be enhanced by processing it with drugs repeatedly. It helps to extract active principles of drugs into fatty media more efficiently and enhance the absorption of drugs.

\section{Method of administration}

The patients eligible for the study was identified from the research settings. They were subjected to thorough clinical evaluations and selected as per the selection criteria. The patient selected for the study was subjected to Deepana-Pachana (for digestive and metabolic correction) internally and Udwarthana externally, Snehapana (oleation), Swedana (sudation) sodhana (purification, virechana- purgation), Samsarjanakrama as a preparatory phase for the administration of study drug.

The patients received Sahacharadi Tailam fourteen times Avarthi for two months. The medicine was given in dropper bottles with a capacity of $30 \mathrm{ml}$ and patients were advised to take 20 drops of medicine with $30 \mathrm{ml}$ of hot water in the morning and evening one 
hour before food at 7 am and $7 \mathrm{pm}$. Patients were advised to visit every 15 days. In a subsequent visit bottle containing $30 \mathrm{ml}$ of study, the drug was given.

\section{Treatment Schedule}

\begin{tabular}{|c|c|c|c|c|}
\hline Treatment & Medicine & Dose & Time & Duration \\
\hline Deepana Pachana & $\begin{array}{l}\text { Gandharvahastadi } \\
\text { Kashayam } \\
\text { Vaiswanara Choorna }\end{array}$ & $\begin{array}{l}48 \mathrm{ml} \\
6 \mathrm{gram}\end{array}$ & $\begin{array}{l}7 \text { am \& } 7 \mathrm{pm} \text { one } \\
\text { hour before food }\end{array}$ & 1-7 days \\
\hline Udvarthana & Kolakulathadi Choorna & Quantity sufficient & $\begin{array}{l}\text { Morning (between } \\
8 \text { am to } 11 \text { am) }\end{array}$ & 1-7 days \\
\hline Snehapana & Rasnadasamoola Gritha & $\begin{array}{l}\text { Starting with } 25 \mathrm{ml} \text { in an } \\
\text { increasing dosage schedule } \\
\text { per day }\end{array}$ & $\begin{array}{l}6 \text { am on an empty } \\
\text { stomach }\end{array}$ & 3-7 days \\
\hline Abyanga- Nadisweda & Balatailam & Quantity sufficient & $\begin{array}{l}\text { Morning (between } \\
8 \text { am to } 11 \mathrm{am} \text { ) }\end{array}$ & 3 days \\
\hline Virechana & Gandharveranda Tailam & $\begin{array}{l}30 \mathrm{ml}-45 \mathrm{ml} \text { with } 150 \mathrm{ml} \\
\text { of warm milk }\end{array}$ & $\begin{array}{l}7 \text { am on an empty } \\
\text { stomach }\end{array}$ & 1 day \\
\hline Samsarjana Krama & $\begin{array}{l}\text { Manda, Peya, Vilepi, Akrutha } \\
\& \text { Kritha Yoosha }\end{array}$ & Quantity sufficient & $8 \mathrm{am} \& 8 \mathrm{pm}$ & 3-7 days \\
\hline Study drug & $\begin{array}{l}\text { Shacharadi Tailam fourteen } \\
\text { times Avarthi }\end{array}$ & $\begin{array}{l}20 \text { drops with } 30 \mathrm{ml} \text { of } \\
\text { warm water }\end{array}$ & $\begin{array}{l}7 \text { am } \& 7 \mathrm{pm} \text { one } \\
\text { hour before food }\end{array}$ & 2 months \\
\hline
\end{tabular}

\section{Study tools}

Case proforma

Movement disorder society-Universal Parkinson's disease rating scale (MDS-UPDRS)

Lab investigation (Liver function test and Renal function test)

\section{Dose of the study drug}

The patients in the study group were given 20 drops of medicine with $30 \mathrm{ml}$ of hot water in the morning and evening one hour before food at 7 am and $7 \mathrm{pm}$.

\section{Diet}

The patients were advised to follow a normal diet.

\section{Assessment}

Assessment of the patient was done in the following schedule:

$1^{\text {st }}$ assessment- Before treatment ( $0^{\text {th }}$ day)

$2^{\text {nd }}$ assessment- After sodhana (on $12^{\text {th }}$ day and may extend to a maximum of $\left.25^{\text {th day }}\right)$

$3^{\text {rd }}$ assessment- After treatment (on $71^{\text {st }}$ day and may extend to a maximum of $85^{\text {th }}$ day)

$4^{\text {th }}$ assessment- 15 days after the completion of study drug

\section{Follow up}

Follow up was done 15 days after the completion of the study drug.

\section{Clinical assessment}

Change in following domains assessed by using MDS-UPDRS

Non-motor aspects of experiences of daily living

Motor aspects of the experience of daily living

Motor symptoms

\section{Methods of statistical analysis}

The mean standard deviation of MDS UPDRS was computed. The effectiveness of the drug was done by Wilcoxen signed-rank test. Data analysis is done using SPSS software.

\section{RESULTS}

On assessing non-motor aspects of experiences of daily living, it showed the significant result in pain and other sensation. $30 \%$ of the patients had no pain and other sensations before treatment and it became $90 \%$ after the intervention. It showed significant results for this symptom after intervention, and it remained as such after follow up. 
By assessing motor aspects of experiences of daily living, tremor causes problems with all activities (grade V: severe) before treatment and it became moderate after intervention and follow up and is seen to be significant. But there were no significant changes seen after sodhana. While comparing the result of the intervention and follow up no changes were observed. Out of the total participants, 5 patients had mild tremors and it became 2 after the intervention.

On examination, the consistency of tremor was severe in $80 \%$ of patients and it became moderate in 6 of the patients after intervention. On observing follow up results no changes were seen. It was observed that the intensity of tremor also reduced after the intervention.

There was a significant result seen in rigidity after sodhana, after intervention and after follow up to that with before treatment. ie. $60 \%$ of patients had slight rigidity (rigidity only detected with activation manoeuvre) in the right upper extremity before treatment and it was absent after sodhana. It remained the same after intervention \& after follow up. On comparing the results after Sodhana and after the intervention, after intervention and follow up, no signifi- cant changes were seen. Similar changes were observed in other extremities.

There were significant results seen in handwriting also. $40 \%$ of patients had moderate difficulty in handwriting; it became 30\% after sodhana and $0 \%$ after intervention and after follow up. When assessing patients after shodhana, the study is not significant. After intervention and after follow up to that with before treatment, it is found to be significant.

On analysing each symptom, there were statistically significant results were seen in pain, tremor, handwriting and rigidity. But bradykinesia, sleep disturbances neuropsychiatric symptoms like depression, anxiety, apathy, autonomic symptoms like urinary problems, constipation, salivation etc. showed statistically no significant results. It was observed in 2 patients that there was an improvement in drug-induced dyskinesia after sodhana and after the intervention. After follow up the dyskinesia remained the same as before treatment. Subjective changes were seen in gait disturbances. After the intervention, the period of levodopa increased. On analysing there was no progression of any symptoms in the entire study period even though Parkinson's disease is a progressive neurodegenerative disease.

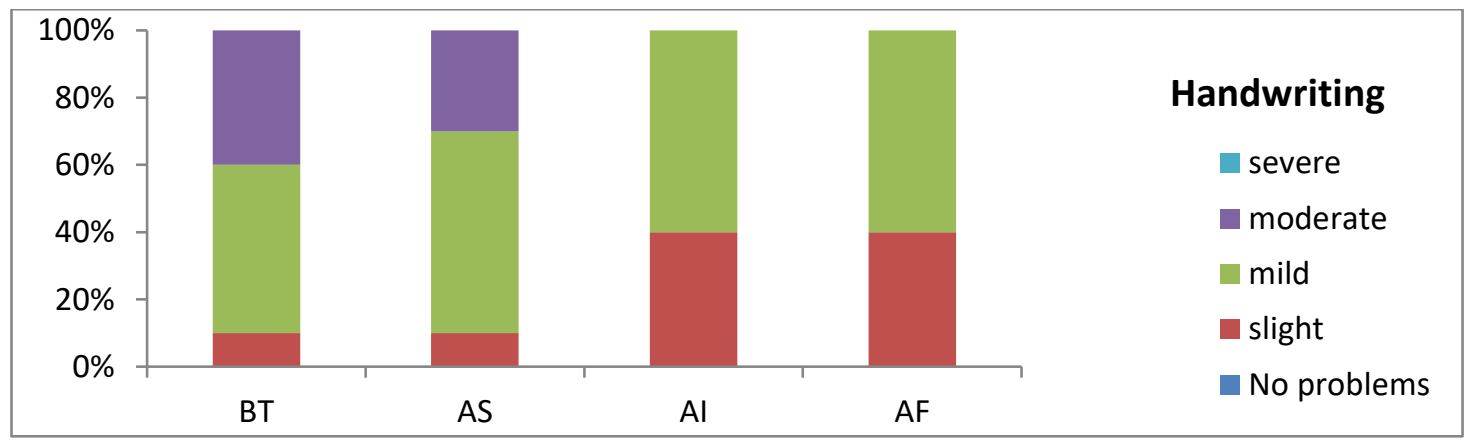

$\left.\begin{array}{rr|r|r|}\hline 100 \% \\ 80 \% \\ 60 \% \\ 40 \% \\ 20 \% \\ 0 \%\end{array}\right]$




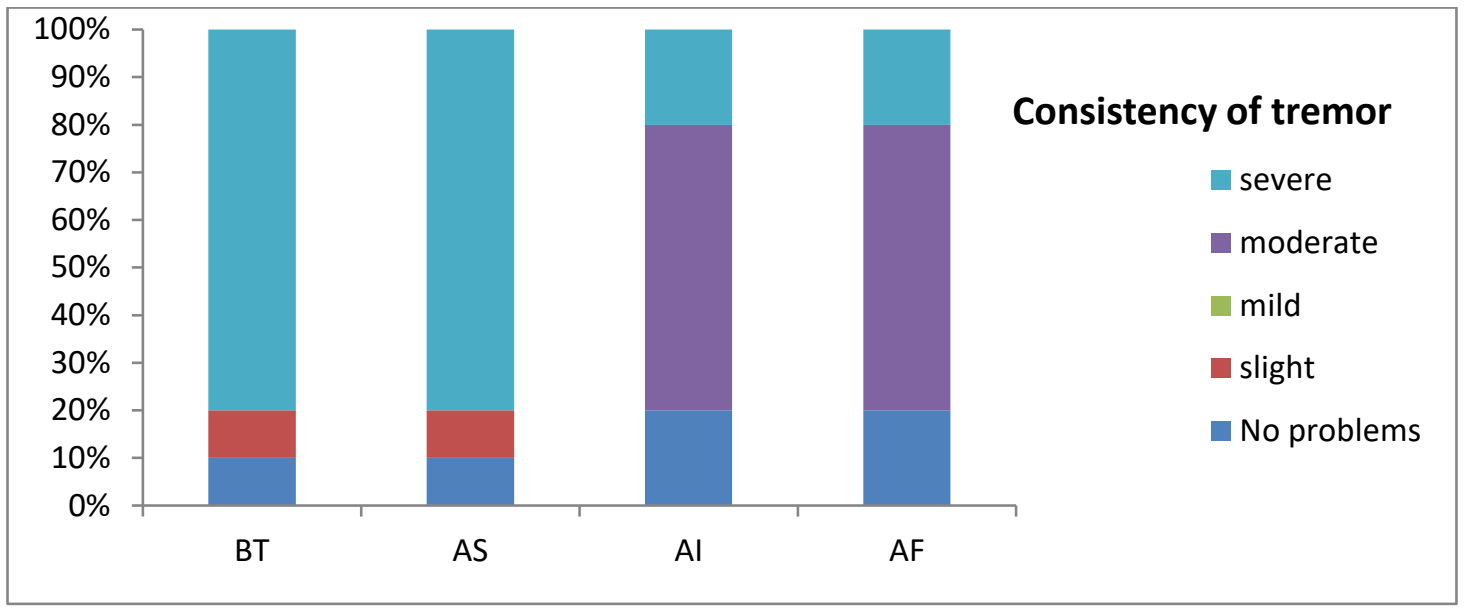

\section{DISCUSSION}

Parkinson's disease is an idiopathic disorder and is one of the major neurodegenerative disorders that affect mainly the old age group ${ }^{[9]}$. It is a progressive disorder that gradually disables the patient. Worldwide, based on the available prevalence studies, there are likely to be more than 6 million people with Parkinson's disease ${ }^{[10]}$. The present study was designed to evaluate the effectiveness of sahacharadi tailam fourteen times avarthi with premedication in improving the Quality of Life of patients with Parkinson's disease as an add on to modern medicine.

\section{Demographic data}

Among 10 patients, $70 \%$ of them were in the age group $60-70 \mathrm{yrs}$, followed by $30 \%$ in $50-60 \mathrm{yrs}$, showing the greater prevalence of the disease in older ages. Among total patients $60 \%$ were male and $40 \%$ were female. As far as marital status is considered, $80 \%$ of the patients were married and $20 \%$ were widowed. This might be due to the fact that all of the patients who participated in the present study were above 40 yrs of age.

It is observed that in this study, $30 \%$ of patients have completed primary education only, $30 \%$ has completed SSLC, $20 \%$ has completed higher secondary and $20 \%$ of them were graduate. Among 10 patients $50 \%$ of patients belong to a middle class, $40 \%$ were in the lower class and $10 \%$ were in the upper class.

Among 10 patients $20 \%$ of patients were manual labourers, $20 \%$ were housewives, and $10 \%$ of them were businessmen. Half of the patients were retired government employees. It includes policemen, clerks and teachers. Among total patients $90 \%$ were Hindu, and $10 \%$ were Muslim. It is observed that in this clinical study $60 \%$ of the patients were from a rural area and $40 \%$ of them were from urban areas.

In this study, $80 \%$ of patients have no addictions, and $10 \%$ of patients were alcoholics and $10 \%$ of them were smokers. It is observed that in this study, $40 \%$ of the patients were Vatapitha Prakrithi, 40\% were Vatakapha Prakrithi and 20\% were Kaphapitha Prakrithi.

\section{Data related to Parkinson's disease}

Among total patients, $50 \%$ of them have their symptoms with chronicity of 1-2 years, $20 \%$ with chronicity between 3-4 years and 30\% with chronicity of 4 years and above.

Among 10 patients all of them were presented with bradykinesia, $90 \%$ have tremors as presenting complaint, $80 \%$ have gait disturbances and $40 \%$ of patients have pain and other sensations. The most prominent relieving factor reported by the patients were sleep (70\%) followed by muscular exertion (30\%). The most prominent aggravating factor reported by the patients were emotions ( $80 \%$ ) followed by rest in $40 \%$ and crowded areas in $30 \%$ of patients.

Among 10 patients $60 \%$ of patients have both constipation and urinary problems, $20 \%$ have excessive salivation and $10 \%$ of patients suffer from paroxysmal sweating. Most of the patients reported depres- 
sion (70\%) followed by anxiety in $60 \%$ of patients and cognitive dysfunction in $10 \%$ of patients.

\section{Outcome variable}

Parkinson's disease (PD) is the most common form of progressive neurodegenerative disorders characterized by bradykinesia (a paucity and slowness of movement), rest tremor, muscular rigidity, short shuffling gait, and flexed posture.

On assessing non-motor aspects of experiences of daily living, it showed the significant result in pain and other sensation. $30 \%$ of the patients had no pain and other sensations before treatment and it became $90 \%$ after the intervention. It showed significant results for this symptom after intervention, and it remained as such after follow up. No significant results were seen in other symptoms like depression, anxiety, urinary problems etc.

By assessing motor aspects of experiences of daily living, tremor causes problems with all activities (grade V: severe) before treatment and it became moderate after intervention and follow up and is seen to be significant. But there were no significant changes seen after Sodhana. While comparing the result of the intervention and follow up no changes were observed. Out of the total participants, 5 patients had mild tremors and it became 2 after the intervention.

On examination, the consistency of tremor was severe in $80 \%$ of patients and it became moderate in 6 of the patients after intervention. On observing follow up results no changes were seen. It was observed that the intensity of tremor also reduced after the intervention.

There was a significant result seen in rigidity after sodhana, after intervention and after follow up to that with before treatment. ie. $60 \%$ of patients had slight rigidity (rigidity only detected with activation manoeuvre) in the right upper extremity before treatment and it was absent after sodhana. It remained the same after intervention \& after follow up. On comparing the results after Sodhana and after the intervention, after intervention and follow up, no significant changes were seen. Similar changes were observed in other extremities.
There were significant results seen in handwriting also. $40 \%$ of patients had moderate difficulty in handwriting; it became $30 \%$ after sodhana and $0 \%$ after intervention and after follow up. When assessing patients after Shodhana, the study is not significant. After intervention and after follow up to that with before treatment, it is found to be significant.

On analysing each symptom, there were statistically significant results were seen in pain, tremor, handwriting and rigidity. But bradykinesia, sleep disturbances neuropsychiatric symptoms like depression, anxiety, apathy, autonomic symptoms like urinary problems, constipation, salivation etc. showed statistically no significant results.

It was observed in 2 patients that there was an improvement in drug-induced dyskinesia after sodhana and after the intervention. After follow up the dyskinesia remained the same as before treatment. Subjective changes were seen in gait disturbances. After the intervention, the period of Levodopa increased. On analysing there was no progression of any symptoms in the entire study period even though Parkinson's disease is a progressive neurodegenerative disease.

\section{Probable mode of action of the drug}

In PD, there is significant vatha kopa along with vitiation of kapha. It is well evident from the Lakshana that the pathology is considered to be Avarana. But it can't be brought under a single avarana. So, a combination of avarana is imposed in the pathology of PD. Since Kapha and Vata plays an important role in Samprapthi of Parkinson's disease, Kapha Vatha Hara Chikitsa should be effective. All types of Sneha Dravya are used in Vatha Vyadhi Chikitsa and Taila is more effective when vatha is associated with kapha $^{[11]}$.

In Sahacharadi Tailam, most of the drugs are Kaphavatha Samana. Most of the drugs have Katu Vipaka, Ushna Virya, and Laghu Ruksha Guna. ${ }^{[12]}$ These properties are important in removing Avarana. In Sahachardi Taila, 6 drugs have brimhana property, 4 drugs have rasayana property and 2 drugs have medhya property $\left[{ }^{13]}\right.$. Since PD is a neurodegenerative disease medhya, rasayana and brimhana properties play an important role. 


\section{CONCLUSION}

- When the Clinical features of Parkinson's disease were analyzed on the basis of Ayurvedic Principles, involvement of Vatha and Kapha Dusthi is observed. From the Lakshana and Upasaya of the disease, the role of avarana in the samprapthi is clear. The kaphavarana occurs over vatha mainly vyana and udana.

- The rookshana and Snehana prayoga administered according to the avastha yields good relief from rigidity.

- Statistical analysis from a clinical trial showed that there is improvement in pain, rigidity, handwriting and tremor.

- There was no progression of any symptoms were observed in the entire study period even though it was a progressive neurodegenerative disease.

- It was observed that there were significant results seen in reducing drug-induced dyskinesia.

- On analyzing data before and after follow up, it can be concluded that the trial drug with premedication is effective in improving the QOL with respect to pain, tremor, handwriting and rigidity of patients with Parkinson's disease.

\section{REFERENCES}

1. Principles of Neurology, Raymond's D. Adams, Maurice Victor and Allan. H. Rooper $-7^{\text {th }}$ edition (2003) Mc. Grow - Hill Co. Inc.

2. Textbook of Neuropathology $3^{\text {rd }}$ edition by Richard. L. Davies, David. M. Robert Son was published by Williams Wilkins.

3. Harrison's Principles of Internal Medicine $15^{\text {th }}$ edition by Eugene Braunwald, Anthony. S. Fauci, Kasper, Hauser, Longo and Sameson, Published by Mc. Graw hill.

4. Brains disease of the nervous system Michaer Donaghy $11^{\text {th }}$ edition published by Oxford University Press.

5. Neurology and Neurosurgery illustrated, Churchill living stone, published by Thimothy Horne.

6. Asthanga Hridaya with Sarvanga Sundara teeka by Bhisagacharya Hari Sasthri paradakara vaidya, published by Chaukamba orientalia.

7. Guide to Clinical Neurology by J.P. Mohr and J.C. Gautier $7^{\text {th }}$ edition by Churchill Living Stone.
8. Asthanga Hridaya with Sarvanga Sundara teeka by Bhisagacharya Hari Sasthri paradakara vaidya, published by Chaukamba orientalia.

9. Davidson's Principles and Practice of medicine $21^{\text {st }}$ edition edited by Nicki R. Colledge, Brian R. Walker and Stuart H. Ralston.

10. Neurological practice - An Indian perspective by Noshir and Wadia, I edition.

11. Astanga Hridaya English Commentary by K.R. Srikantha Murthy - Krishnadas academy (1991).

12. Astanga Hridaya English Commentary by K.R. Srikantha Murthy - Krishnadas academy (1991).

13. Indian Meteria Medica by Nadkarni A.K. and K.M. Nadkarni, popular prakashan, Mumbai.

\section{Source of Support: Nil \\ Conflict of Interest: None Declared}

How to cite this URL: Jinsa I et al: Effectiveness Of Sahacharadi Tailam Fourteen Times Avarthi With PreMedication In Quality Of Life Of Parkinson's Disease As An Add On To Modern Medicine. International Ayurvedic Medical Journal \{online\} 2021 \{cited November 2021\} Available from: http://www.iamj.in/posts/images/upload/3171_3178.pdf 